\title{
Micro Spectrophotometric Determination and Cloud Point Extraction of Sulphadimidine Sodium in Pure form and Pharmaceutical Drug
}

Saadiyah Ahmed Dhahir *

Received 21/5/2018, Accepted 14/11/2018, Published 2/6/2019
Esraa Amer Kadhim

Ruqaya Hashem Abed AL-Gani

\begin{abstract}
:
Two simple, rapid, and useful spectrophotometric methods were suggest or the determination of sulphadimidine sodium (SDMS) with and without using cloud point extraction technique in pure form and pharmaceutical preparation. The first method was based on diazotization of the Sulphdimidine Sodium drug by sodium nitrite at $5{ }^{\circ} \mathrm{C}$, followed by coupling with $\alpha$-Naphthol in basic medium to form an orange colored product. The product was stabilized and its absorption was measured at $473 \mathrm{~nm}$. Beer's law was obeyed in the concentration range of (1-12) $\mu \mathrm{g} \cdot \mathrm{ml}^{-1}$ Sandell's sensitivity was $0.03012 \mu \mathrm{g} \cdot \mathrm{cm}^{-1}$, the detection limit was $0.0277 \mu \mathrm{g} \cdot \mathrm{ml}^{-1}$, and the limit of Quantitation was $0.03605 \mu \mathrm{g} \cdot \mathrm{ml}^{-1}$. The second method was the cloud point extraction (CPE) using Trtion X-114 as surfactant. Beer's law was obeyed in the concentration range of (112) $\mu \mathrm{g} \cdot \mathrm{ml}^{-1}$ Sandell's sensitivity was $0.02958 \mu \mathrm{g} \cdot \mathrm{cm}^{-1}$, the detection limit was $0.01745 \mu \mathrm{g} \cdot \mathrm{ml}^{-1}$, and the limit of quantitation was $0.028303 \mu \mathrm{g} \cdot \mathrm{ml}^{-1}$. All variables including the reagent concentration, reaction time, color stability period, and mole ratio were studied in order to optimize the reaction conditions. The mole ratio for the composition of product is (1:1). Both methods were effectively useful to the determination of sulphdimidine sodium in pharmaceutical dose form. The attained results were in a good agreement with the official and other methods in the literature .No interference were observed from the commonly encountered additives and excipients.
\end{abstract}

Key words: Cloud Point Extraction, $\alpha-$ Naphthol, Sulphdimidine Sodium, Triton X-114.

\section{Introduction:}

Sulfonamides are one of the oldest groups of pharmacologically energetic material used in veterinary medication to day(1).Their discovery in 1935, suggested the start of a new era in the treatment of a varied range of bacterial diseases and a number of protozoan toxicities(2).

The pharmaceutical sulfa of the first antibiotics, terms of manufacturers folic acid were discovered by tincture known as Prontosil (3) which are effective in the body work antibiotics. Sulfonamide preparation authority Sodium salt has temperate solubility(4).

Sulphadimidine Sodium (SDMS), famous as sulfamethazine Sodium, is one of the greatest broadly used sulfonamides in animals. It has supposedly been effectually used contrary to a wide-ranging of contagious diseases, a public healing medication, particularly for livestock, pigs and fowls. It is accepted for healing coccidiosis and has been used as a growing fields in pigs and livestock.

Department of Chemistry, College of Science for Woman, University of Baghdad, Baghdad, Iraq.

*Corresponding author: sadiataher@gmail.com
It is not agreed for use in lactating dairy cows and placing chickens of age less than 16 weeks(5). Over-all characterizes of sulfadimidine Sodium are certain in fig. 1 (6).

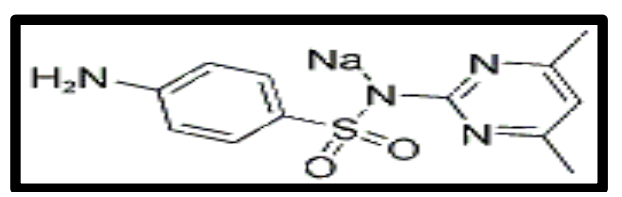

Figure 1. Structure of sulphadimidine sodium

Diazonium salts are important raw materials for the preparation of some aromatic compounds, drugs, dyes, and other organic compounds. These salts are useful in the analysis process. They have electrolytic properties that enable them to be combined with other high-density electronic compounds such as phenols and amino acids(7), consisting of colored compounds that are suitable for use in estimating very small amounts of organic compounds, light absorption or polygraphy by measuring the propagation current.

These salts can be extracted by cloud point extraction method(8) .Cloud point extraction (CPE) 
is based on the phase behavior of non- ionic surfactants in aqueous solution(9), which exhibits phase separation after an increase in temperature or the addition of a salting out agent (10).Separation and preconcentration based on (CPE) are becoming an important and practical application of surfactant in analytical chemistry(11). This study focuses to developing easy method and sensitive to determination of SDMS. The experimental conditions are free of heating and environmental friendly because small amounts of chemicals are used (12).

\section{Materials and Methods: \\ Instruments:}

UV-Vis spectrophotometer: SHIMADZU, Double beam UV-Vis, model UV-1800 made in Japan. The range of wavelength (190-1100) nm, quartz cell with $1 \mathrm{~cm}$ path., Water Bath: A thermostat water bath, Memmert, made in Germany, Electric Balance: Sartorius (0.0000), made in Germany, Centrifuge: Triup International Corp. TRIU 800 Centrifuge, made in Korea \& PH meter: HANNA, PH meter, HI 83141.

\section{Preparation Standard Solutions}

All reagents and materials used in this work were of high purity materials. Distilled water was used to dissolve and prepare solutions. Stock solution of Sulphadimidine Sodium (SDMS) $1000 \mu \mathrm{g} . \mathrm{ml}^{-1}$ was prepared by dissolving $0.1 \mathrm{gm}$ in a small amount of distilled water then completed to $100 \mathrm{ml}$ by distilled water. Stock solution of reagent $\left[\alpha\right.$-Naphthol] $1000 \mu \mathrm{g} . \mathrm{ml}^{-1}$ was prepared by dissolving $0.1 \mathrm{gm}$ in $25 \mathrm{ml}$ ethanol then diluting to the mark in $100 \mathrm{ml}$ volumetric flask by distilled water. (1\%) Sodium nitrite solution was prepared by dissolving $1 \mathrm{~g}$ from $\mathrm{NaNO}_{2}$ in distilled water and diluting to the mark in $100 \mathrm{ml}$ volumetric flask. (1\%) Sulfamic acid solution was prepared by dissolving $1 \mathrm{~g}$ from $\mathrm{H}_{3} \mathrm{NSO}_{3}$ with distilled 100 ml.(10\% V/V) Different surfactants[TritonX-100, TritonX-114, Tween 20, Tween 80,STAP, SDS] were prepared by diluting $10 \mathrm{ml}$ with distilled to $100 \mathrm{ml}$ volumetric flask. $1000 \mu \mathrm{g} \cdot \mathrm{ml}^{-1}$ stock solution of interferences were prepared by dissolving the organic compound $0.1 \mathrm{gm}$ from the following [Lactose, Starch, Arabic Gum, Glucose, Talc, Trimethoprim] and inorganic compound $[0.2579 \mathrm{gm}$, $0.2500 \mathrm{gm}, 2.9 \mathrm{gm}]$ of $\mathrm{Ca}_{3}\left(\mathrm{PO}_{4}\right)_{2}, \mathrm{CaCO}_{3}, \mathrm{FeCl}_{3}$ in distilled water and diluting to the mark in $100 \mathrm{ml}$ volumetric flask.1M from Phosphoric acid, Nitric acid, Sulphuric acid, Hydrochloric acid and Acetic acid were prepared by proper dilution.

\section{General Procedure for Azo Coupling:}

The prepared Azo Coupling product are added in volumetric flask $(10 \mathrm{ml})$ in ice bath, $1 \mathrm{ml}$ of Sulphadimidine Sodium (SDN) (1000 $\left.\mu \mathrm{g} \mathrm{ml}^{-1}\right), 1 \mathrm{ml}$ for hydrochloric acid, $1 \mathrm{ml}$ for sodium nitrate $(1 \%)$, $1 \mathrm{ml}$ for sulphamic acid (1\%), $1 \mathrm{ml}$ for $\alpha$ Naphthol $\left(1000 \mu \mathrm{g} \mathrm{ml} \mathrm{ml}^{-1}\right)$, at last $1 \mathrm{ml}$ is added for sodium hydroxide and the volume is commpleted by distilled water. Then absorbance is measured by UV-VIS. Absorption spectra with maximum wavelength are shown in fig. 2

\section{General procedure for CPE:}

A typical experiment of cloud point includes the following steps: taking the volumetric flask $(10 \mathrm{ml})$ and use the optimum condition of azo coupling. Add $1 \mathrm{ml}$ for surfactant (10\%) and complete the volume by distilled water. The content of volumetric flask is transferred to centrifuge test tube then the mixture is placed in a water bath for 20 minutes at $60{ }^{\circ} \mathrm{C}$ and separated by centrifugation for 20 minutes at $4000 \mathrm{rpm}$. Test tube is taken in ice bath to increased viscosity micelles layer for 1minutes, then become easily separated. The separated sediments dissolved by $1 \mathrm{ml}$ of ethanol and its absorption spectrum are recorded in Fig. 2.

\section{Results and Discussion:}

First Methods: Spectrophotometric Determination of Sulphadimidine Sodium (SDMS) by Oxidation Coupling Reactions. Optimization Parameters for Reaction.

All of the factors that affect the absorbance of azo dye product are optimized to improve the sensitivity and detection limit for the determination of the drugs .All optimization work under wavelength at $473 \mathrm{~nm}$. 


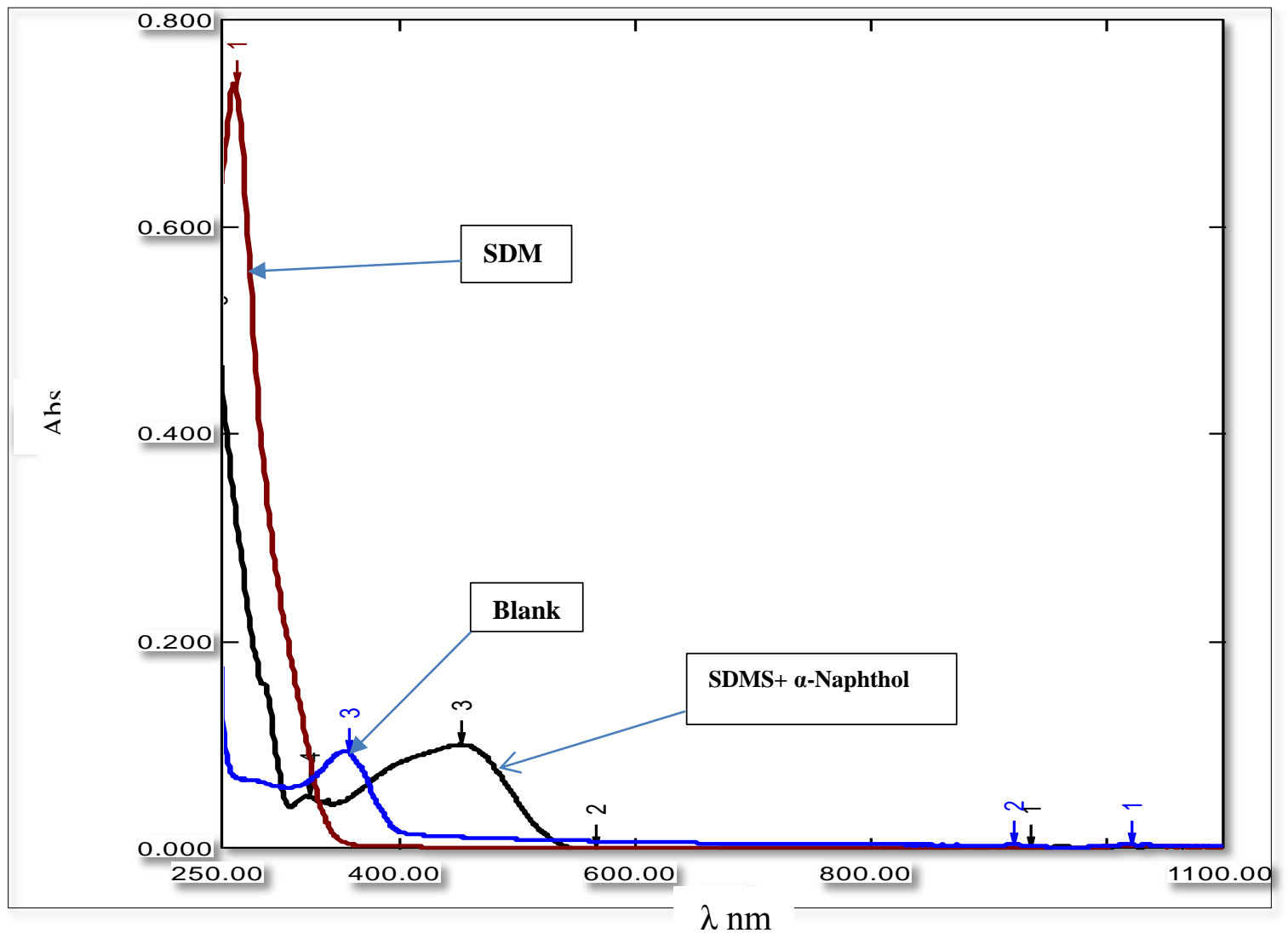

Figure 2. Absorbance spectra of the Resulting Dye. SDMS

\section{Effect of Acid Type.}

In this study, $0.5 \mathrm{M}$ of different acid $[\mathrm{HCl}$, $\mathrm{H}_{2} \mathrm{SO}_{4}, \mathrm{HNO}_{3}, \mathrm{H}_{3} \mathrm{PO}_{4}$ and $\left.\mathrm{CH}_{3} \mathrm{COOH}\right]$ are used. The same procedure that [ $1 \mathrm{ml}$ of drug SDMS , $1 \mathrm{ml}$ of each acid, $1 \mathrm{ml}$ of $\mathrm{NaNO}_{2}, 1 \mathrm{ml}$ of $\mathrm{H}_{3} \mathrm{NSO}_{3}, 1 \mathrm{ml} \alpha$ Naphthol and $1 \mathrm{ml}$ of $\mathrm{KOH}$ ] are mixed in $10-\mathrm{mL}$ volumetric flask and volume is completed by distilled water to-form the diazonium salt. After that, the absorbance is measured at maximum wavelength for drug.

It is clear from this study that the acetic acid gives higher absorbance for SDMS, this acid is a few of uses in subsequent experiments as shown in the Table 1 and Fig. 3 .

Table 1. The absorbance of different acid with SDMS

\begin{tabular}{cc}
\hline 0.5 M (acid) 1ml & Abs. \\
\hline $\mathrm{HCl}$ & 0.140 \\
$\mathrm{HNO}_{3}$ & 0.053 \\
$\mathrm{H}_{2} \mathrm{SO}_{4}$ & 0.128 \\
$\mathrm{H}_{3} \mathrm{PO}_{4}$ & 0.039 \\
$\mathrm{CH}_{3} \mathrm{COOH}$ & 0.153 \\
\hline
\end{tabular}

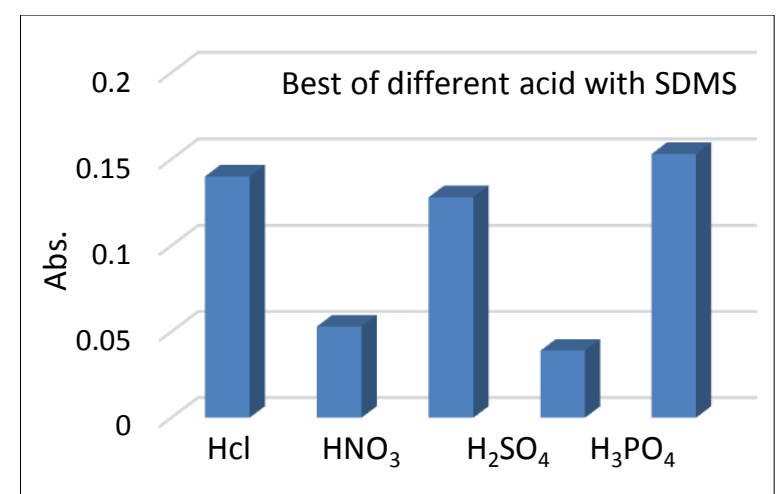

Figure 3. Absorbance of different acid

\section{Effect of Optimum Volume of 0.5M Acetic Acid}

The same addition for SDMS is $[1 \mathrm{ml}$ drug, with varying volumes of $0.5 \mathrm{CH}_{3} \mathrm{COOH}$ from $(0.1$ 1) $\mathrm{ml}, 1 \mathrm{ml} \mathrm{NaNO}{ }_{2}, 1 \mathrm{ml} \mathrm{H}_{3} \mathrm{NSO}_{3}, 1 \mathrm{ml} \alpha$-Naphthol and $1 \mathrm{ml}$ of $\mathrm{KOH}$ in $10 \mathrm{ml}$ volumetric flask and the volume is completed by distill water .Then the absorbance are measured and the optimum volume for higher absorbance that fixed for sequence experiment $0.5 \mathrm{ml}$ as shown in Table 2 and Fig. 4. 
Table 2. Data of the absorbance of different volume to acetic acid with SDMS.

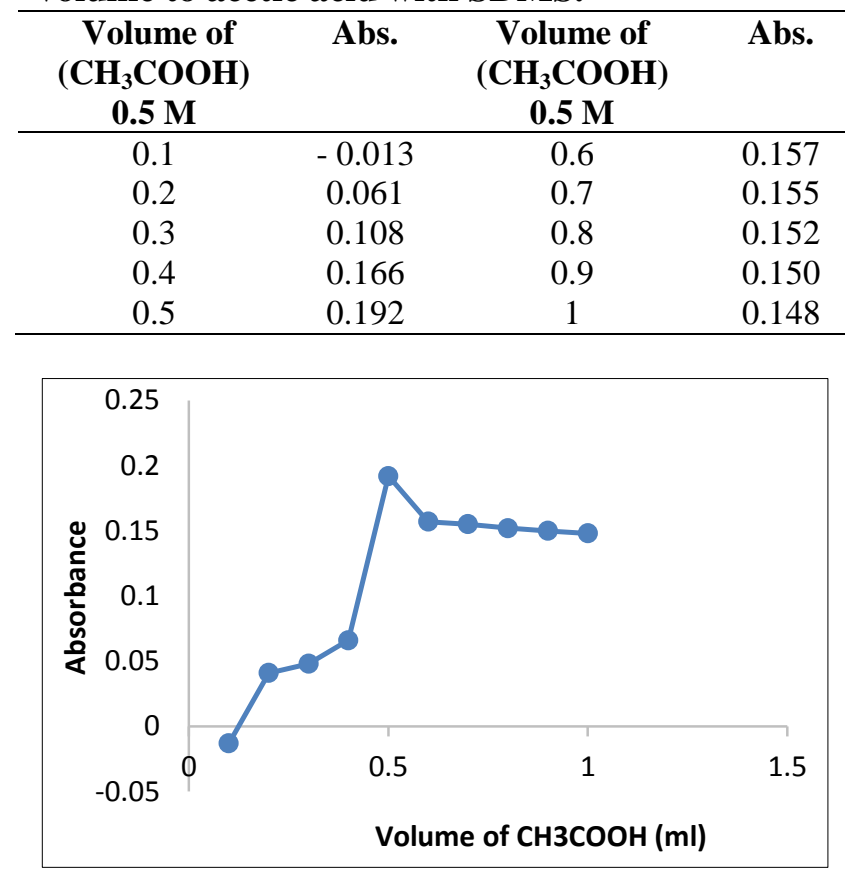

Figure 4. The Volume of $0.5 \mathrm{M} \mathrm{CH3COOH} \mathrm{ml}$ with SDMS

It is obvious that absorbance increase with increasing the volume of acid, suddenly the absorbance decrease because the primary amine becomes inactive (13) .

\section{Effect of Base Type}

In this experiment using different basic [NaOH, $\mathrm{KOH}, \mathrm{K}_{2} \mathrm{CO}_{3}, \mathrm{Na}_{2} \mathrm{CO}_{3}, \mathrm{NH}_{4} \mathrm{OH}, \mathrm{NaHCO}_{3}$ ] and that follow the addition [1 $1 \mathrm{ml}$ SDMS, $0.5 \mathrm{ml}$ $\mathrm{CH}_{3} \mathrm{COOH}, 1 \mathrm{ml} \mathrm{NaNO}{ }_{2}, 1 \mathrm{ml} \mathrm{H}_{3} \mathrm{NSO}_{3}, 1 \mathrm{ml} \alpha-$ Naphthol and $1 \mathrm{ml}$ of each base] in $10 \mathrm{ml}$ volumetric flask. Then maximal absorbance for the base is $\mathrm{KOH}$ as shown in Table 3 and Fig. 5.

Table 3. Data of the absorbance of different base with SDMS

\begin{tabular}{cc}
\hline 0.5 M (base) 1ml & Abs. \\
\hline $\mathrm{NaOH}$ & 0.183 \\
$\mathrm{KOH}$ & 0.272 \\
$\mathrm{NH}_{4} \mathrm{OH}$ & 0.004 \\
$\mathrm{Na}_{2} \mathrm{CO}_{3}$ & 0.123 \\
$\mathrm{~K}_{2} \mathrm{CO}_{3}$ & 0.174 \\
$\mathrm{NaHCO}_{3}$ & 0.061 \\
\hline
\end{tabular}

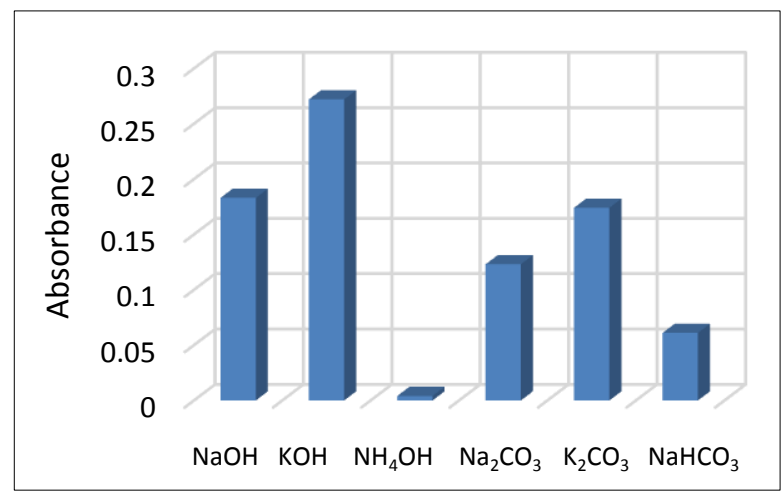

Figure 5. The absorbance different base with SDMS

It is clear the potassium hydroxide gives the higher absorbance, this base is fixed in subsequent(14).

\section{Effect of Optimum Volume of 0.5M KOH.}

The same addition for SDMS is $[1 \mathrm{ml}$ drug, $\mathbf{0 . 5} \mathrm{ml} \mathrm{CH}{ }_{3} \mathrm{COOH}, 1 \mathrm{ml} \mathrm{NaNO}{ }_{2}, 1 \mathrm{ml} \mathrm{H}_{3} \mathrm{NSO}_{3}, 1 \mathrm{ml}$ $\alpha$-Naphthol and (0.1-1) $\mathrm{ml}$ of $\mathrm{KOH}$ in $10 \mathrm{ml}$ volumetric flask and the volume is completed by distill water .Then the absorbance and the optimum volume for higher absorbance that fixed at $1 \mathrm{ml}$ for sequence experiment are measured as shown in Table4 and Fig. 6.

Table 4. Data of the absorbance of different volume of KOH.

\begin{tabular}{cc}
\hline (KOH) 0.5 M & Abs. \\
\hline 0.1 & .0 .069 \\
0.2 & 0.106 \\
0.3 & 0.119 \\
0.4 & 0.124 \\
0.5 & 0.158 \\
0.6 & 0.220 \\
0.7 & 0.246 \\
0.8 & 0.291 \\
0.9 & 0.301 \\
1 & 0.312 \\
1.1 & 0.094 \\
1.2 & 0.074 \\
\hline
\end{tabular}

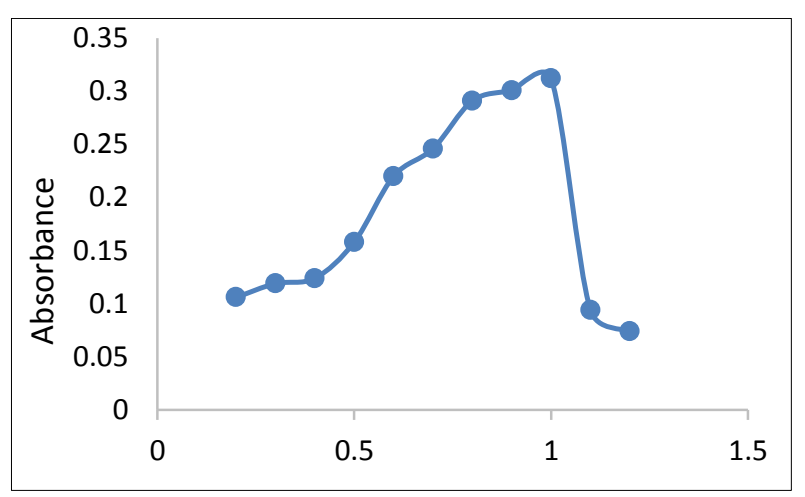

Figure 6. Different Volume of KOH with SDMS

It is evident that absorbance increases with increasing the volume of $\mathrm{KOH}$, but suddenly decrease the absorbance because the decomposition happens when increased basicity and formation 
diazotate ions that may couple and agree with previous studies (15).

Effect of Optimum Volume of $1 \%$ Sodium nitrite.

The same additions [ $1 \mathrm{ml}$ for SDMS, $\mathbf{0 . 5} \mathrm{ml}$ $\mathrm{CH}_{3} \mathrm{COOH}$ with varying volume of $1 \% \quad \mathrm{NaNO}_{2}$ from (0.1-1) $\mathrm{ml}, 1 \mathrm{ml} \mathrm{H}_{3} \mathrm{NSO}_{3}, 1 \mathrm{ml} \alpha-\mathrm{Naphthol}$ and $0.5 \mathrm{ml} \mathrm{KOH}$ are put in volumetric flask $10 \mathrm{ml}$ and the higher absorbance of optimum volume fixed at $0.3 \mathrm{ml}$ for sequence experiment, as shown in Table 5 and Fig. 7.

Table 5. Data of the absorbance of different volume of Sodium nitrite.

\begin{tabular}{cc}
\hline 1\% Sodium nitrite & Abs. \\
\hline 0.1 & 0.336 \\
0.2 & 0.347 \\
0.3 & 0.357 \\
0.4 & 0.350 \\
0.5 & 0.323 \\
0.6 & 0.271 \\
0.7 & 0.264 \\
0.8 & 0.216 \\
0.9 & 0.194 \\
\hline
\end{tabular}

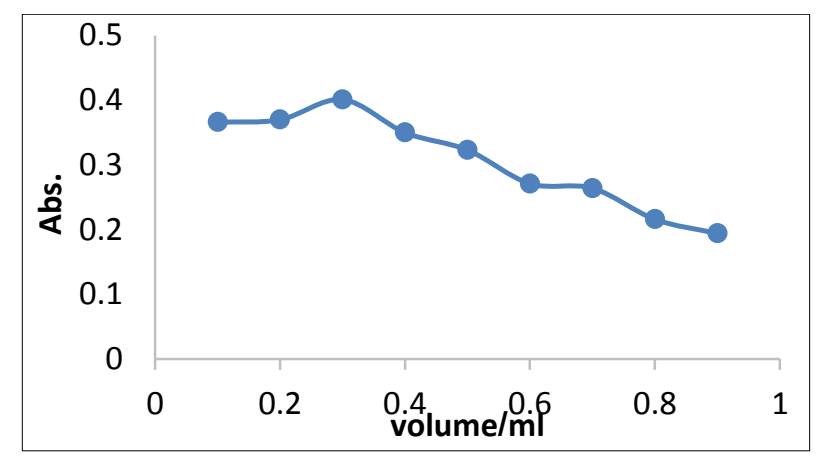

Figure 7. Absorbance of 1\% $\mathrm{NaNO2} / \mathrm{ml}$

It is clear that the absorbance increases with increasing the volume of $\mathrm{NaNO}_{2}$, but the signals decrease because the nitrate toxic because a high rate of pollutants affecting on diazonium salt (16).

\section{Effect of Optimum Volume of 1\% Sulphamic acid.}

The same additions [ $1 \mathrm{ml}$ for SDMS, $\mathbf{0 . 5} \mathrm{ml}$ $\mathrm{CH}_{3} \mathrm{COOH}, \mathbf{0 . 3 m l ~} \mathrm{NaNO}_{2}$ with varying volume of $1 \% \mathrm{H}_{3} \mathrm{NSO}_{3}$ from (0.1-1) $\mathrm{ml}, 1 \mathrm{ml} \alpha$-Naphthol and $0.5 \mathrm{ml} \mathrm{KOH}$ are put in volumetric flask $10 \mathrm{ml}$ and the higher absorbance of optimum volume is fixed at $0.09 \mathrm{ml}$ for sequence experiment as shown in Table 6 and Fig. 8.
Table 6. Data of the absorbance of different volume of Sulphamic acid.

\begin{tabular}{cccc}
$\begin{array}{c}\text { Volume of 1\% } \\
\text { Sulphamic acid }\end{array}$ & Abs. & $\begin{array}{c}\text { Volume of 1\% } \\
\text { Sulphamic acid }\end{array}$ & Abs. \\
\hline 0.07 & 0.199 & 0.3 & 0.194 \\
0.08 & 0.241 & 0.4 & 0.177 \\
0.09 & 0.363 & 0.5 & 0.164 \\
0.1 & 0.286 & 0.6 & 0.154 \\
0.2 & 0.202 & & \\
\hline
\end{tabular}

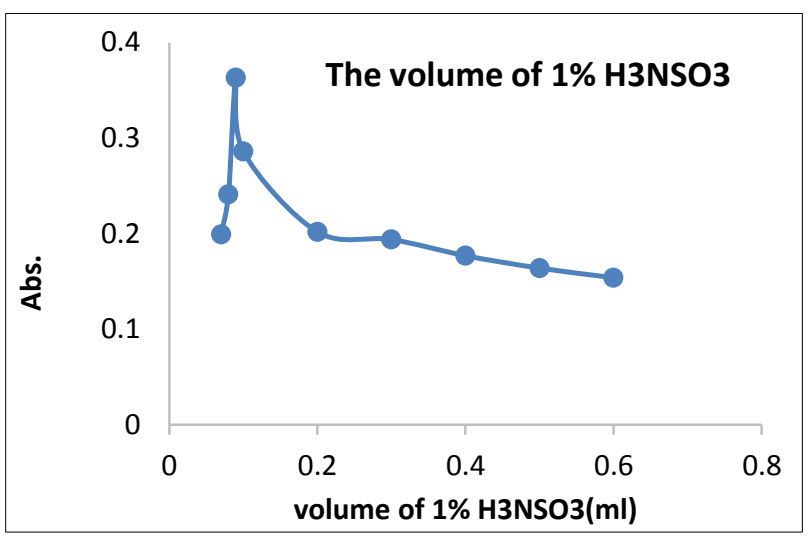

Figure 8.the volume of $1 \% \mathrm{H}_{3} \mathrm{NSO}_{3}$

In this graph. it is clear that the absorbance increases with increasing the volume of Sulphamic acid, but the signals decrease suddenly because this volume of sulphamic acid is used to removes nitrite and escape of nitrogen gas(17).

\section{Effect of Optimum Volume of $\left(100 \mu \mathrm{g} \mathrm{mL} \mathrm{L}^{-1}\right)$ Reagent}

The same additions [ $1 \mathrm{ml}$ for SDMS, $0.5 \mathrm{ml}$ $\mathrm{CH}_{3} \mathrm{COOH}, 0.3 \mathrm{ml} \mathrm{NaNO}_{2}, 0.09 \mathrm{ml} \mathrm{H}_{3} \mathrm{NSO}_{3}$, with varying volume from $(0.1-0.9) \mathrm{ml} \alpha$-Naphthol and $0.5 \mathrm{ml} \mathrm{KOH}$ are put in volumetric flask $10 \mathrm{ml}$ and the higher absorbance of optimum volume $0.4 \mathrm{ml}$ at maximum wavelength is fixed for sequence experiment as shown in Table7 and Fig.9.

Table 7. Data of the absorbance of different volume of $\alpha$-Naphthol with SDMS

\begin{tabular}{cccc}
\hline $\begin{array}{c}\text { Volume of } \boldsymbol{\alpha}- \\
\text { Naphthol }\end{array}$ & Abs. & $\begin{array}{c}\text { Volume of } \boldsymbol{\alpha}- \\
\text { Naphthol }\end{array}$ & Abs. \\
\hline 0.1 & 0.178 & 0.6 & 0.365 \\
0.2 & 0.237 & 0.7 & 0.357 \\
0.3 & 0.333 & 0.8 & 0.340 \\
0.4 & 0.402 & 0.9 & 0.329 \\
0.5 & 0.374 & & \\
\hline
\end{tabular}




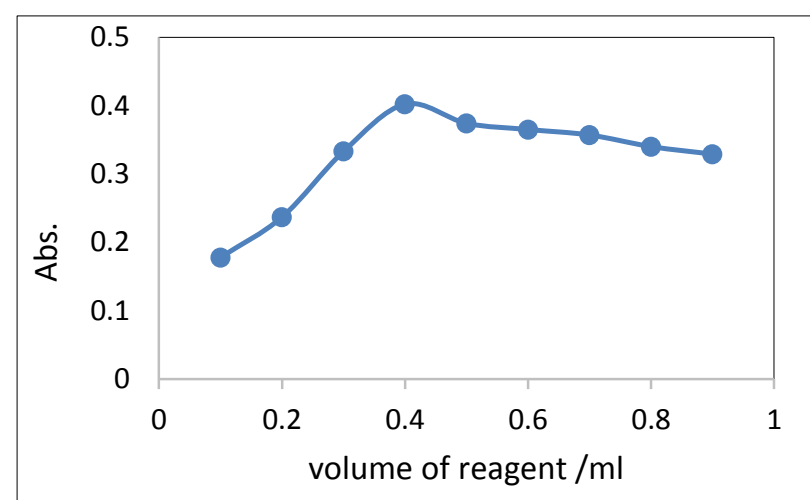

Figure 9. volume of reagent $/ \mathrm{ml}$ with SDMS

The absorbance increases with increasing the volume of reagent but suddenly decreases because this is required volume for coupling with SDMS.

\section{Effect of Reaction Time on the of Stability of the} Product

The optimum volumes are going to be applied for the color product of SDMS [1ml SDMS, $0.5 \mathrm{ml} \mathrm{CH} \mathrm{CH}_{3} \mathrm{COOH}, 0.3 \mathrm{ML} \mathrm{NaNO}_{2}, 0.09 \mathrm{ml}$ $\mathrm{H}_{3} \mathrm{NSO}_{3}, \quad 0.4 \mathrm{ml} \quad \alpha$-Naphthol, $\left.1 \mathrm{ml} \quad \mathrm{KOH}\right]$ in volumetric flask $10 \mathrm{ml}$. The stability of the product is one of the important factors that diazotization and clouding reaction depend on, so the time needed is (0-60) minutes Then the absorbance is measured and the high reader at a high maximum wavelength is taken and recorded. It is clear that the time of product remains stable for SDMS is 50 minutes show in Table 8 and Fig. 10.

Table 8. The absorbance of different time of SDMS.

\begin{tabular}{cccc}
\hline Time & Abs. & Time & Abs. \\
\hline 0 & 0.430 & 35 & 0.496 \\
5 & 0.450 & 40 & 0.497 \\
10 & 0.460 & 45 & 0.498 \\
15 & 0.461 & 50 & 0.499 \\
20 & 0.463 & 55 & 0.483 \\
25 & 0.469 & 60 & 0.475 \\
30 & 0.478 & 65 & 0.465 \\
\hline
\end{tabular}

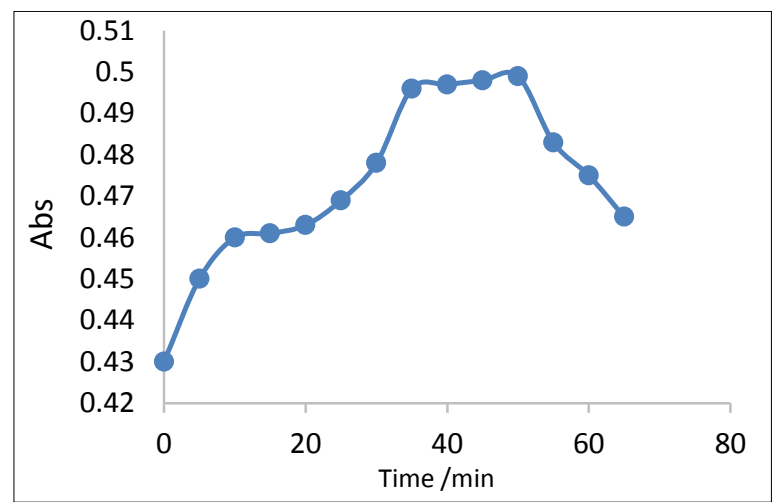

Figure 10. Time stability color/minutes of SDMS

\section{Effect of the Order of Addition}

In this study, the effect of sequence of addition with optimum volumes depends on the same procedure is applied. The absorbance is measured and recorded in Table 9.

$\mathbf{R}: \alpha$-Naphthol, $\mathbf{H}$ : acid $\left(\mathrm{CH}_{3} \mathrm{COOH}\right), \mathbf{N}: \mathrm{NaNO} 2, \mathbf{S}$ : H2NSO3, D: Drug (SDMS), B: Base (KOH). It is evident that the best addition is the order two because it gives the upper absorbance as shown in Fig. 11.

Table 9. Data of different addition of SDMS

\begin{tabular}{ccc}
\hline No. & Addition & Abs. \\
\hline 1 & $\mathrm{R}+\mathrm{H}+\mathrm{N}+\mathrm{S}+\mathrm{D}+\mathrm{B}$ & 0.264 \\
2 & $\mathrm{D}+\mathrm{H}+\mathrm{N}+\mathrm{S}+\mathrm{R}+\mathrm{B}$ & 0.521 \\
3 & $\mathrm{D}+\mathrm{H}+\mathrm{N}+\mathrm{B}+\mathrm{R}+\mathrm{S}$ & 0.301 \\
4 & $\mathrm{D}+\mathrm{B}+\mathrm{R}+\mathrm{N}+\mathrm{H}+\mathrm{S}$ & 0.151 \\
5 & $\mathrm{R}+\mathrm{B}+\mathrm{D}+\mathrm{H}+\mathrm{N}+\mathrm{S}$ & 0.165 \\
6 & $\mathrm{R}+\mathrm{H}+\mathrm{N}+\mathrm{B}+\mathrm{D}+\mathrm{S}$ & 0.027 \\
\hline
\end{tabular}

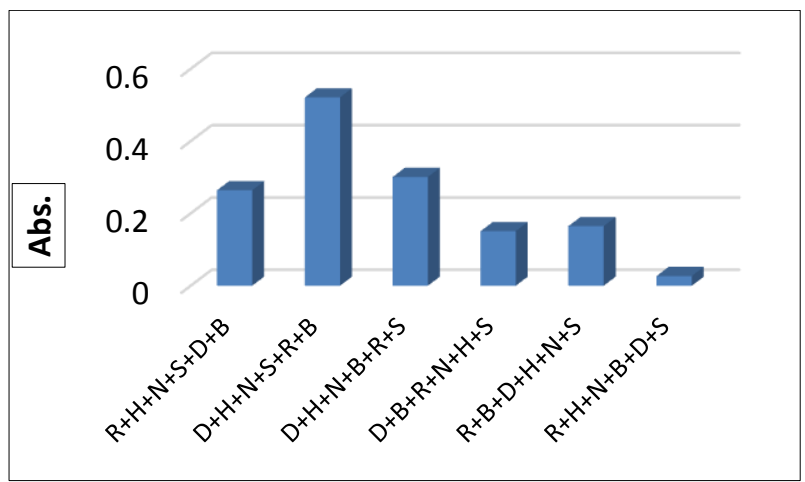

Figure (11): Different addition with SDMS.

\section{Effect of Solvent:}

All the compounds of the optimum parameters for SDMS are dissolved in a volumetric flask and this volume is completed for different solvents and the absorbance is measured.

In this study shows the best solvent is water. It is sensitive, cheap, economical and nontoxic as shown in Table 10 and Fig .12.

Table 10. Data of different solvent with SDMS.

\begin{tabular}{ccc}
\hline NO. & Solvent & Abs. \\
\hline 1 & Water & 0.520 \\
2 & Ethanol & 0.408 \\
3 & Methanol & 0.342 \\
4 & Acetonitril & 0.437 \\
5 & 1-Propanol & 0.442 \\
6 & Acetone & 0.054 \\
\hline
\end{tabular}




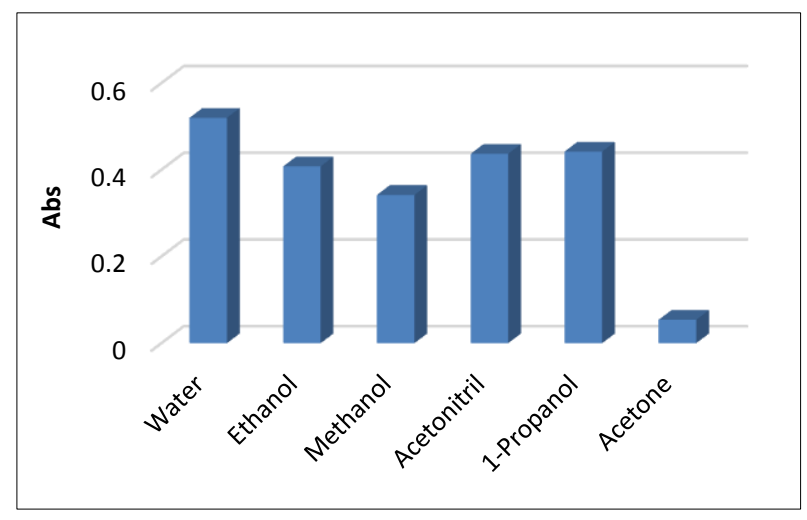

Figure 12. Different solvent with SDMS

\section{Effect of Temperature:}

The rest additions are optimal conditions then diluted with distilled water in volumetric flask in $10 \mathrm{ml}$, then the effect of different temperature on the color product have been $(5-60){ }^{\mathrm{O}} \mathrm{C}$. The absorbance is measured and this result is recorded in Table 11.

It is evident the best temperature is $20 C^{O}$ because is give the best absorbance shown in Fig.13.

Table 11. Data of Absorbance to Temperature in the formation of color product and stabilization

\begin{tabular}{cc}
\hline Time & Abs. \\
\hline 5 & 0.350 \\
15 & 0.482 \\
20 & 0.521 \\
30 & 0.493 \\
40 & 0.484 \\
50 & 0.439 \\
60 & 0.419 \\
\hline
\end{tabular}

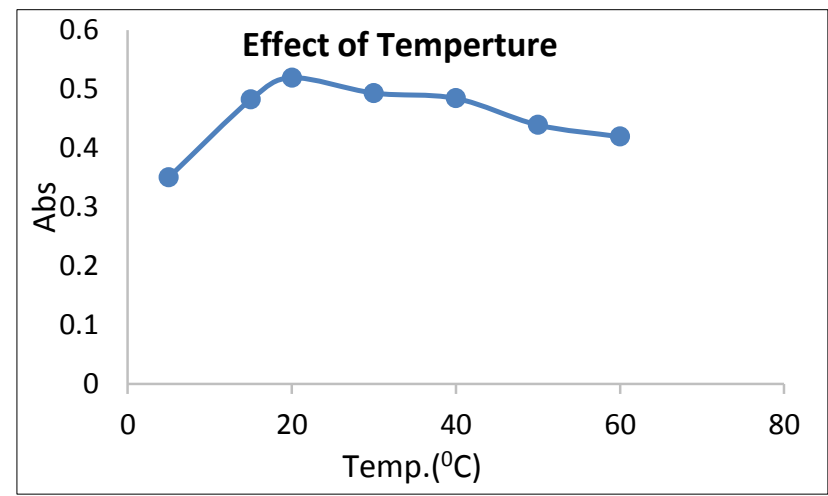

Figure 13. Effect of Temperature with SDMS

Stoichiometric Determination of Product Continuous Variation Method (18)

A series of different volumes of reagent and drug are prepared (0.1-0.9) $\mathrm{ml}$, with concentration $\left(4 \times 10^{-4} \mathrm{M}\right)$ in volumetric flask $10 \mathrm{ml}$.The additions are optimal condition and the volume is complete by distilled water (10). Then absorbance is measured by UV-VIS at $\lambda \max =473 \mathrm{~nm}$. The stoichiometric ratio between reagent[R] and drug [D] result 1:1as shown in Table 12 and Fig .14

Table 12. Data of absorbance for Continuous Variation Method Result for SDMS

\begin{tabular}{ccc}
\hline $\begin{array}{c}\text { Volume of } \\
\text { Drug/ml }\end{array}$ & $\begin{array}{c}\text { Volume of } \\
\text { Reagent/ } \mathbf{~ m l}\end{array}$ & Abs. \\
\hline 0.1 & 0.9 & 0.039 \\
0.2 & 0.8 & 0.090 \\
0.3 & 0.7 & 0.132 \\
0.4 & 0.6 & 0.170 \\
0.5 & 0.5 & 0.203 \\
0.6 & 0.4 & 0.185 \\
0.7 & 0.3 & 0.155 \\
0.8 & 0.2 & 0.114 \\
0.9 & 0.1 & 0.070 \\
\hline
\end{tabular}

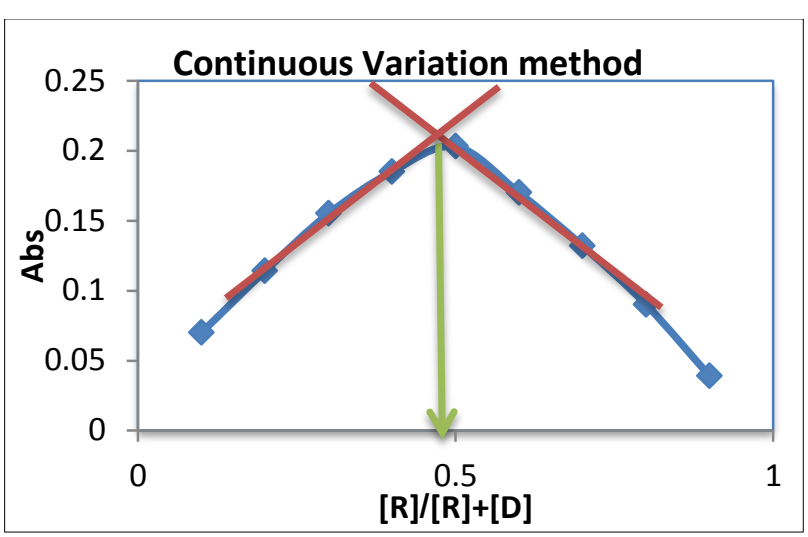

Figure 14. Continuous Variation method of SDMS

\section{Mole Ratio Method}

In this method the volume of drug is fixed at I ml with concentration $\left(4 \times 10^{-4} \mathrm{M}\right)$ and the volume of reagent changes (0.5-4.5 ml). The optimum of addition is completed by distilled water in volumetric flask $10 \mathrm{ml}$ and the absorbance is measured by UV-VIS at $\lambda \max =473 \mathrm{~nm}$. The stoichiometric ratio between reagent $[\mathrm{R}]$ and drug [D] result 1:1as shown in Table 13 and Fig 15

Table 13. Data of Absorbance Mole Ratio Method.

\begin{tabular}{cc}
\hline Volume of Reagent/ $\mathbf{~ m l}$ & Abs. \\
\hline 0.5 & 0.151 \\
1 & 0.333 \\
1.5 & 0.399 \\
2 & 0.401 \\
2.5 & 0.410 \\
3 & 0.415 \\
3.5 & 0.425 \\
4 & 0.427 \\
4.5 & 0.433 \\
\hline
\end{tabular}




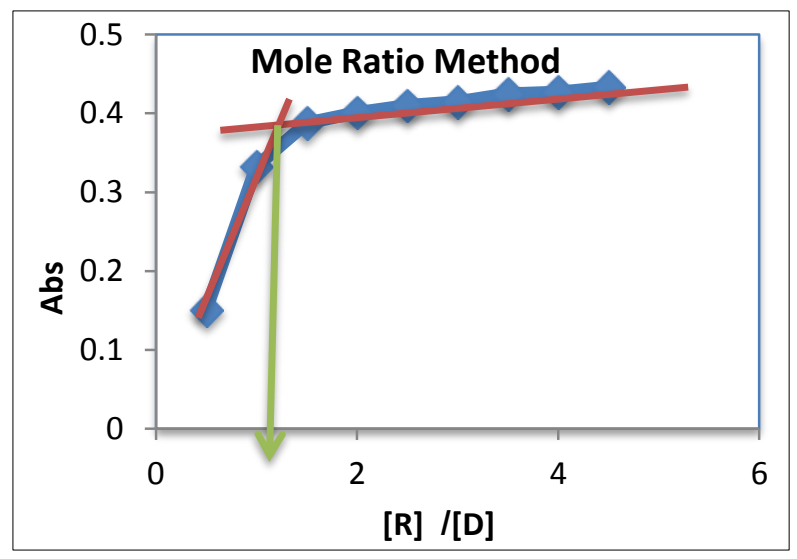

Figure 15. Mole Ratio Method of SDMS.

Calibration Curve for complex of SDMS - $\alpha$ -

Naphthol

In this study, the solution is prepared in volumetric flask $10 \mathrm{ml}$ containing increasing concentration of SDMS (1-12) $\mu \mathrm{g} \mathrm{mL}^{-1}$ by taken $\left[\begin{array}{llllll}0.5 & \mathrm{ml} & \mathbf{C H}_{3} \mathbf{C O O H}, & 0.3 \mathrm{ml} & \mathbf{N a N O} & \end{array}, 0.09 \mathrm{ml}\right.$ $\mathbf{H}_{2} \mathbf{N S O}_{3}, 0.4 \mathrm{ml} \boldsymbol{\alpha}$-Naphthol, $\left.1 \mathrm{ml} \mathbf{K O H}\right]$. The volume is completed by distilled water and the absorbance is measured by UV-VIS at maximum wave length against a blank solution prepares same condition without the drug. Linear calibration graph is established by blotting absorbance against concentration of SDMS, it found (1-12) $\mu \mathrm{g} \mathrm{mL}^{-1}$ obeys Bear Law. The molar absorption coefficient of product equals $\left(9,970 \times 10^{3} \mathrm{~L} \cdot \mathrm{mol}^{-1} \cdot \mathrm{cm}^{-1}\right)$ and sandell's sensitivity $\left(0.03012 \mu \mathrm{g} \mathrm{mL}^{-2}\right)$. The result as shown in Fig 16.

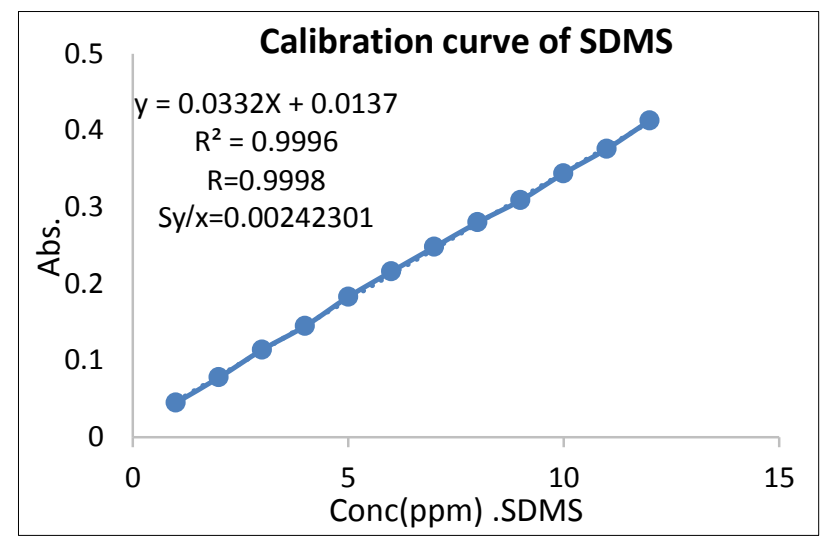

Figure 16. Calibration Curve of SDMS.

\section{Effect of interference.}

In this study effect of interference expected are present with SDMS by adding $1 \mathrm{ml}(1000 \mathrm{ppm})$, and the rest of optimum addition in volumetric flask 10 $\mathrm{ml}$ and complete by distilled water. Then the absorbance is measured by UV-VIS.

Table 14. Data of Absorbance of interference

\begin{tabular}{ccccc}
\hline NO. & 100ppm interference & Abs. & Recovery \% & $\mathbf{E}_{\text {rel }} \%$ \\
\hline 1 & Lactose & 0.337 & 97.54 & -2.46 \\
2 & Starch & 0.341 & 98.77 & -1.23 \\
3 & Arabic Gum & 0.343 & 99.25 & -0.75 \\
4 & Glucose & 0.342 & 99.038 & -0.962 \\
5 & Talc & 0.334 & 96.73 & -3.27 \\
6 & $\mathrm{Ca}_{3}\left(\mathrm{PO}_{4}\right)_{2}$ & 93.769 & -6.231 \\
7 & $\mathrm{CaCl}_{3}$ & 0.325 & 90.79 & -9.21 \\
8 & $\mathrm{FeCl}_{3}$ & 0.315 & 92.422 & -7.578 \\
9 & $\mathrm{CoCl}_{2}$ & 0.320 & 94.068 & -5.932 \\
10 & $\mathrm{CaCl}_{2}$ & 0.326 & 91.05 & -8.956 \\
11 & $\mathrm{NiCl}_{2}$ & 0.316 & 90.04 & -9.956 \\
12 & Tri methyprine & 0.313 & 93.468 & -6.532 \\
13 & Without interference & 0.323 & 100.4006 & 0.04006 \\
\hline
\end{tabular}

This result showed in Table 14 indicate there is no interaction between interference and SDMS (19).
The Stability Constant of Color Product.

The stability constant $\mathrm{K}$ is shown in the Table 15.

Table 15. Data of the Stability Constant of Color Product of SDMS.

\begin{tabular}{|c|c|c|c|c|c|c|}
\hline $\begin{array}{l}\text { Volume of } 4 \times 10^{-} \\
{ }^{4} \mathrm{M} \text { of } \mathrm{SDMS} / \mathrm{ml}\end{array}$ & $\begin{array}{l}\text { Final con. } \\
\text { SDMS /M }\end{array}$ & As* & Am* & $\boldsymbol{\alpha}$ & K(L...Mol $\left.{ }^{-1}\right)$ & $\begin{array}{c}\text { Mean of } \\
\text { K }\left(\text { L.Mol }^{-1}\right)\end{array}$ \\
\hline 0.3 & $1.2 \times 10^{-3}$ & 0.108 & 0.111 & 0.02703 & $4.01 \times 10^{5}$ & $2.22 \times 10^{6}$ \\
\hline 0.5 & $2 \times 10^{-3}$ & 0.186 & 0.189 & 0.01587 & $1.17 \times 10^{6}$ & \\
\hline 0.7 & $2.8 \times 10^{-3}$ & 0.259 & 0.261 & $7.6628 \times 10^{-3}$ & $5.09 \times 10^{6}$ & \\
\hline
\end{tabular}

It is clear the stability constant is high, so the dye formed is very stable.

$\mathrm{Am}=$ the high absorbance, as $=$ the few absorbance.

\section{Accuracy and Precision Test}

The Table 16 shows the accuracy and precision of SDMS, which is studied at different concentration 
$(12,9,6,3)$. It is clear that this result has a good accuracy and precision.

Table 16. Accuracy and Precision Test of SDMS

\begin{tabular}{|c|c|c|c|c|c|c|}
\hline $\begin{array}{c}\text { Amount of } \\
\text { SDMS } / \mu \mathrm{g} \mathrm{mL} \mathbf{~}^{-1}\end{array}$ & *Found & Recovery \% & $\begin{array}{c}\text { Average } \\
\text { Recovery \% }\end{array}$ & $\mathbf{E}_{\text {rel }} \%$ & $\begin{array}{c}\text { Average } \\
\mathbf{E}_{\mathrm{rel}} \%\end{array}$ & RSD\% \\
\hline 12 & 11.097928 & 99.8267 & 103.3793 & -0.1733 & 3.3786 & 1.3021 \\
\hline 9 & 9.54438 & 106.0478 & & 6.0477 & & 0.9192 \\
\hline 6 & 5.9556 & 99.26 & & -0.74 & & 0.82005 \\
\hline 3 & 3.25149 & 108.383 & & 8.38 & & 3.0562 \\
\hline
\end{tabular}

$*=$ Average for five determination.

\section{6- Application:}

sThe proposed method is applied on [Montajat Pharmaceuticals. Saudi Arabia] injection (SULJAT) that contains (200mg) from Sulphadimidine Sodium in $100 \mathrm{ml})$.The result is good and summarized in Table (17).

Table 17. Data of Accuracy and Precision Test.

\begin{tabular}{|c|c|c|c|c|c|c|}
\hline $\begin{array}{c}\text { Amount of } \\
\text { SDMS / } \mu \mathrm{g} \mathrm{mL}^{-1}\end{array}$ & *Found & Recovery \% & $\begin{array}{c}\text { Average } \\
\text { Recovery \% }\end{array}$ & $\mathbf{E}_{\text {rel }} \%$ & $\begin{array}{c}\text { Average } \\
\mathbf{E}_{\text {rel }} \%\end{array}$ & RSD\% \\
\hline 12 & 11.9728 & 99.773 & 98.474 & -0.2266 & -1.5253 & 0.4134 \\
\hline 9 & 9.0090 & 100.1 & & 0.1 & & 0.5982 \\
\hline 6 & 5.8765 & 97.94 & & -2.058 & & 0.6678 \\
\hline 3 & 2.8825 & 96.0833 & & -3.9166 & & 1.585 \\
\hline
\end{tabular}

$*=$ Average for five determination.

\section{Second Method: Spectrophotometric} Determination of Sulphadimidine Sodium (SDMS) with Using Cloud Point Extraction Technique.

\section{Effect Type of Surfactant with SDMS}

The surfactant plays an important role in cloud point extraction process .The basic practical dependes of micells for extraction .The solution contains [1 $1 \mathrm{ml}$ SDMS, $0.5 \mathrm{ml} \quad \mathrm{CH}_{3} \mathrm{COOH}, 0.3 \mathrm{ml}$ $\mathrm{NaNO}_{2}, \mathbf{0 . 0 9} \mathrm{ml} \mathrm{H} \mathrm{H}_{3} \mathrm{NSO}_{3}, \mathbf{0 . 4 m l} \alpha$-Naphthol , $1 \mathrm{ml}$ $\mathrm{KOH}]$ and $1 \mathrm{ml}$ of each surfactant is added in volumetric flask $10 \mathrm{ml}$ and the volume is completed by distilled water.at $60 \mathrm{C}^{\mathrm{O}}$ for 20 minutes then separated by centrifugated at $4000 \mathrm{rpm}$ for 20 minutes ,that separated and dissolved in $1 \mathrm{ml}$ ethanol and measured by UV-VIS at $\lambda \max =473 \mathrm{~nm}$ and the result is shown in Table18.

It is clear from this result that the surfactant Triton $\mathrm{X}-114$ increases the absorbance and efficiently of cloud point extraction (20) in Fig.17.

Table 18. Data of Absorbance for different surfactant with SDMS.

\begin{tabular}{ccc}
\hline No. & Surfactant & Abs. \\
\hline 1 & Tween 20 & 0.190 \\
2 & Triton X-100 & 0.215 \\
3 & Tween 80 & 0.207 \\
4 & SDS & 0.235 \\
5 & Triton X-114 & 0.276 \\
6 & CTAP & 0.041 \\
\hline
\end{tabular}

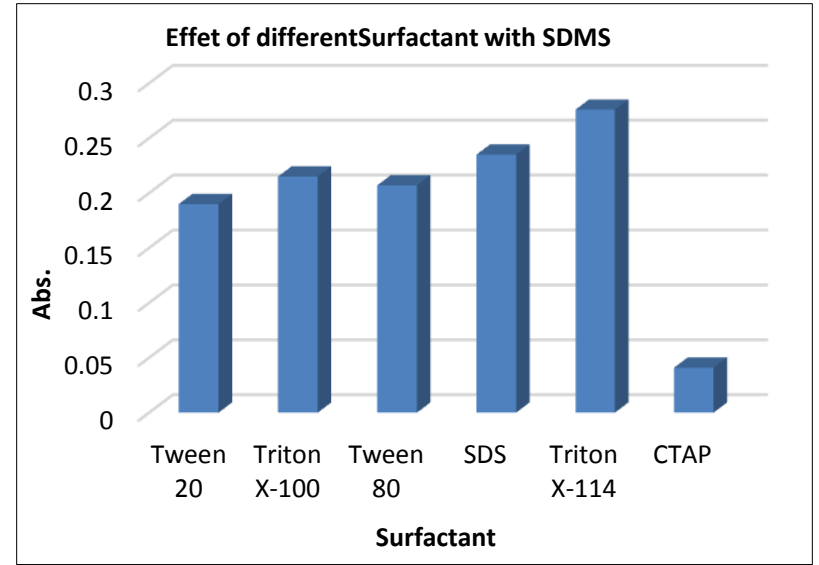

Figure 17. Effect of different Surfactant with SDMS

\section{Effect of Triton X-114 Volume}

The solution contain the former addition and uses varying volumes of $10 \%$ Triton X-114 in volumetric flask $10 \mathrm{ml}$ and complete the mark by distilled water. It is heated at $60 \mathrm{C}^{\mathrm{O}}$ for 20 minutes to form cloud point and separated by centrifugation at $4000 \mathrm{rpm}$ for 20 minutes, $1 \mathrm{ml}$ ethanol will be added and measured by UV-VIS at $\lambda \max =473 \mathrm{~nm}$.

It is obvious that the absorbance increases with increasing the volume of Triton X-114, that effects on the efficiency of extraction (21), suddenly this absorbance decreases below the optimum volume due to micelles catch enough the amount of hydrophopic product. The best volume of Triton X114 is $1.4 \mathrm{ml}$ as shown in Fig. 18 and Table 19 
Table 19. Data of Absorbance of Volume Triton X-114.

\begin{tabular}{cc}
\hline Volume of Triton X-114 & Abs. \\
\hline 0.2 & 0.156 \\
0.4 & 0.162 \\
0.6 & 0.235 \\
0.8 & 0.252 \\
1 & 0.278 \\
1.2 & 0.290 \\
1.4 & 0.307 \\
1.6 & 0.298 \\
1.8 & 0.286 \\
2 & 0.236 \\
\hline
\end{tabular}

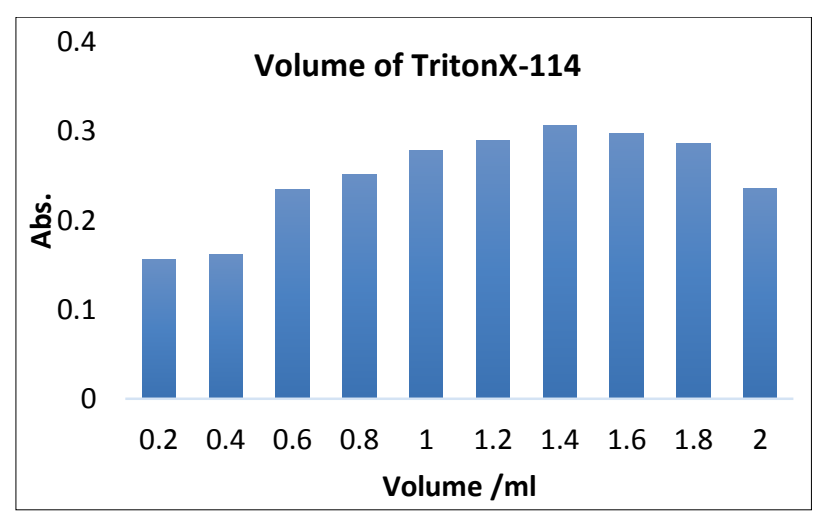

Figure 18.Volume of TritonX-114 with SDMS

\section{Effect of Equilibrium Temperature}

In series of $10 \mathrm{ml}$ that contain $[\mathbf{1 m l}$ $\mathrm{SDN}, \mathbf{0 . 5} \mathrm{ml} \mathrm{CH}_{3} \mathrm{COOH}, \mathbf{0 . 3} \mathrm{ml} \mathrm{NaNO}_{2}, \mathbf{0 . 0 9} \mathrm{ml}$ $\mathrm{H}_{3} \mathrm{NSO}_{3} \quad \mathbf{0 . 4} \mathrm{ml} \quad \alpha$-Naphthol , $1 \mathrm{ml} \mathrm{KOH}, \mathbf{1 . 4} \mathrm{ml}$ Triton X114]in volumetric flask $10 \mathrm{ml}$, then complete to the mark by distilled water. The varied temperature $\left(35-70{ }^{\circ} \mathrm{C}\right)$ for 20 minutes to form cloud point and separated by centrifugation at 4000rpm for 20 minutes, $1 \mathrm{ml}$ ethanol will be added and measured by UV-VIS at $\lambda \max =473 \mathrm{~nm}$ and recorded as shown in Fig. 20.

The result recorded that the best temperature are $50{ }^{\circ} \mathrm{C}$ as shown in Table 20 and Fig.19.

Table 20. Data of Absorbance of Varied Temperature.

\begin{tabular}{cc}
\hline Temperature & Abs. \\
\hline 35 & 0.217 \\
40 & 0.286 \\
45 & 0.301 \\
50 & 0.331 \\
55 & 0.290 \\
60 & 0.288 \\
65 & 0.276 \\
\hline
\end{tabular}

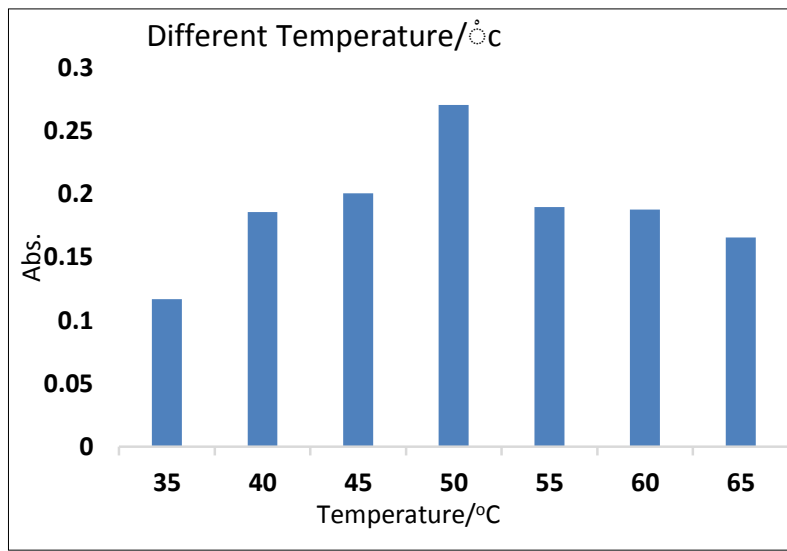

Figure 19. Different Temperature/ $C^{0}$ with SDMS

\section{Effect of Incubation Time}

The solution [ $1 \mathrm{ml} \mathrm{SDN,} \mathbf{0 . 5} \mathrm{ml} \mathrm{CH}_{3} \mathrm{COOH}$, 0.3ml $\mathrm{NaNO}_{2}, 0.09 \mathrm{ml} \mathrm{H}_{3} \mathrm{NSO}_{3}, 0.4 \mathrm{ml} \alpha$-Naphthol, $\mathbf{1 m l} \mathrm{KOH}, \mathbf{1 . 4} \mathrm{ml}$ Triton X114] is prepared in volumetric flask $10 \mathrm{ml}$ and the volume is complete by distilled water at temperature $50{ }^{\circ} \mathrm{C}$ and the incubation time for(5-35minutes) to form cloud point and separated by centrifugation at $4000 \mathrm{rpm}$ for 20 minutes, $1 \mathrm{ml}$ ethanol will be added and measured by UV-VIS at $\lambda \max =473 \mathrm{~nm}$. The best of incubation time is 20 minutes as shown in the Table 21 and Fig. 20.

Table 21. Data of absorbance of Incubation Time

\begin{tabular}{cc}
\hline Time $/$ min & Abs. \\
\hline 5 & 0.245 \\
10 & 0.268 \\
15 & 0.306 \\
20 & 0.341 \\
25 & 0.296 \\
30 & 0.273 \\
35 & 0.260 \\
\hline
\end{tabular}

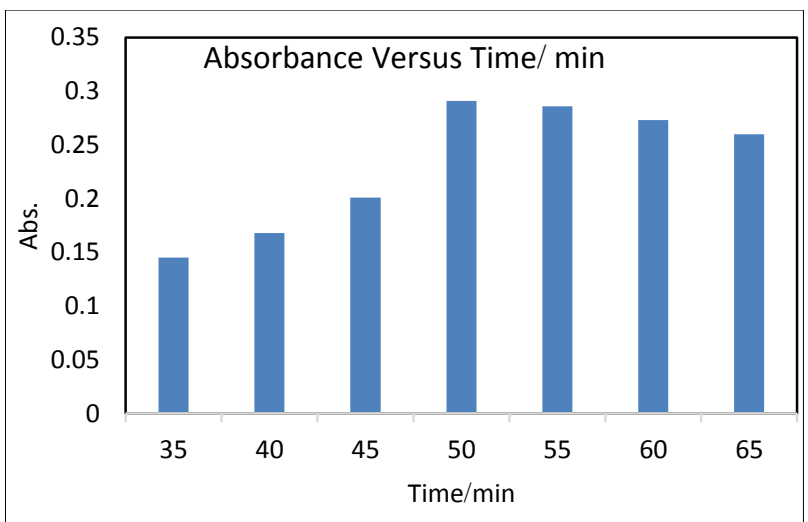

Figure 20.Absorbance of different incubation time.

\section{Preparation of Calibration Curve in CPE}

The prepared solution prepared increasing concentration $\left(1-12 \mu \mathrm{g} \mathrm{mL} \mathrm{m}^{-1}\right)$ by taking $[\mathbf{0 . 5} \mathrm{ml}$ $\mathrm{CH}_{3} \mathrm{COOH}, \mathbf{0 . 3} \mathrm{ml} \mathrm{NaNO}, 0.09 \mathrm{ml} \mathrm{H}_{3} \mathrm{NSO}_{3}, 0.4 \mathrm{ml}$ $\alpha$-Naphthol , 1ml KOH,1.4 ml Triton X114], and in 
volumetric flask $10 \mathrm{ml}$ the volume is completed by distilled water at temperature $50^{\circ} \mathrm{C}$ and the incubation time for(20minutes) to form cloud point and separated by centrifugation at 4000rpm for 20 minutes, $1 \mathrm{ml}$ ethanol will be added and measured by UV-VIS at $\lambda \max =473 \mathrm{~nm}$ and show the result in Fig (21).

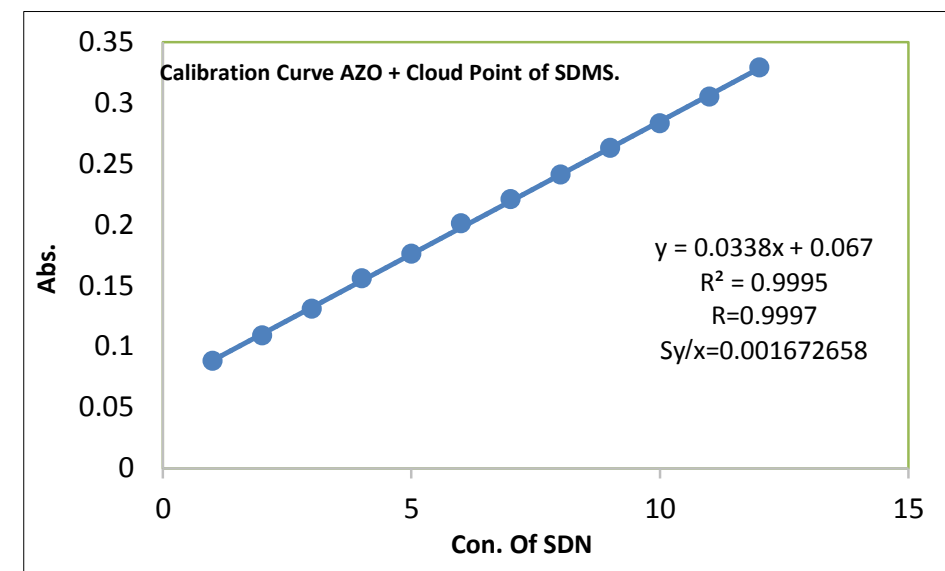

Figure 21. Calibration Curve AZO + Cloud Point of SDMS.

\section{Accuracy and Precision Test}

The table 22 show the accuracy and precision for SDMS with CPE, which are studied at different concentrations $(12,9,6,3)$. It is clear that this result has a good accuracy and precision as shown in Table 22.

Table 22. Data of Accuracy and Precision Test

\begin{tabular}{ccccccc}
\hline $\begin{array}{c}\text { Amount of SDMS / } \boldsymbol{\mu g} \\
\mathbf{m L}^{-\mathbf{1}}\end{array}$ & *Found & Recovery \% & $\begin{array}{c}\text { Average Recovery } \\
\mathbf{\%}\end{array}$ & $\begin{array}{c}\mathbf{E}_{\text {rel }} \% \\
\begin{array}{c}\text { Average } \\
\mathbf{E}_{\text {rel }} \%\end{array}\end{array}$ & $\begin{array}{c}\text { RSD\% } \\
12\end{array}$ \\
\hline 12.0118 & 100.0983 & & 0.098 & 3 & 0.3018 \\
9 & 9.0650 & 100.722 & 100.2538 & 0.722 & 0.2538 & 0.9943 \\
6 & 5.9763 & 99.605 & & 0.395 & 0.9905 \\
3 & 3.0177 & 100.59 & & 0.59 & 0.9808 \\
\hline
\end{tabular}

$*=$ Average for five determination.

\section{Application:}

The proposed method is applied on (silphdimidine sodium $33.3 \%$ injection. Jorden), that contain (33.3 gm each $100 \mathrm{gm})$.The result is good and summarized in Table 23.

Table 23. Data of Accuracy and Precision Test

\begin{tabular}{|c|c|c|c|c|c|c|}
\hline $\begin{array}{c}\text { Amount of SDMS / } \mu \mathrm{g} \\
\mathrm{mL}^{-1}\end{array}$ & *Found & Recovery \% & $\begin{array}{c}\text { Average Recovery } \\
\% \\
\end{array}$ & $\mathbf{E}_{\text {rel }} \%$ & $\begin{array}{c}\text { Average } \\
\mathbf{E}_{\text {rel }} \% \\
\end{array}$ & RSD\% \\
\hline 12 & 11.8956 & 99.8956 & \multirow{4}{*}{99.5298} & $\begin{array}{c}- \\
1.1041\end{array}$ & \multirow{4}{*}{-0.4575} & 0.5583 \\
\hline 9 & 8.9111 & 99.0122 & & $\begin{array}{c}- \\
0.9377\end{array}$ & & 1.7135 \\
\hline 6 & 5.9691 & 99.485 & & -0.515 & & 2.0230 \\
\hline 3 & 3.0218 & 100.7266 & & 0.7266 & & 2.7868 \\
\hline
\end{tabular}

$*=$ Average for five determination.

Comparison of the AZO-Coupling with Cloud Point Extraction Methods for SDMS.
The final result of the AZO-Coupling with Cloud Point Extraction for SDMS Methods as shown in Table 24. 
Table 24. Comparison of the AZO-Coupling with Cloud Point Extraction Methods for SDMS.

\begin{tabular}{|c|c|c|}
\hline Parameter & AZO-Coupling Method & CPE Method \\
\hline Color of Product & Reddish orange & Red \\
\hline$\lambda \max$ & 473 & 473 \\
\hline Regression equation & $y=0.0332 X+0.0137$ & $y=0.0338 x+0.067$ \\
\hline Standard deviation of regression & 0.00242301 & 0.001672658 \\
\hline Correlation coefficient (r) & 0.9998 & 0.9997 \\
\hline C.L for slop $\left(\mathrm{b} \pm \mathrm{t} \mathrm{S}_{\mathrm{b}}\right)$ at $99 \%$ & $0.0332 \pm 0.0064220$ & $0.0318 \pm 0.00443$ \\
\hline C.L for Intercept $\left(b \pm t S_{a}\right)$ at $99 \%$ & $0.0137 \pm 0.04726$ & $0.067 \pm 0.0326$ \\
\hline Concentration range $\left(\mu \mathrm{g} \mathrm{ml}^{-1}\right)$ & $1-12$ & $1-12$ \\
\hline Limit of Detection $\left(\mu \mathrm{g} \mathrm{ml}^{-1}\right)$ & 0.0277 & 0.01745 \\
\hline Limit of Quantitative $\left(\mu \mathrm{g} \mathrm{ml}^{-1}\right)$ & 0.03605 & 0.028303 \\
\hline Sandell's Sensitivity $\left(\mu \mathrm{g} \mathrm{ml}^{-1}\right)$ & 0.03012 & 0.02958 \\
\hline Molar absorbance $\left(\mathrm{L} \cdot \mathrm{mol}^{-1} \cdot \mathrm{cm}^{-1}\right)$ & $9.970 \times 10^{3}$ & $10.1505 \times 10^{3}$ \\
\hline Composition of product & $1: 1$ & \\
\hline Recovery \% & $99.8267-108.383$ & $94.578-101.338$ \\
\hline $\mathrm{RSD} \%$ & $0.82005-3.0562$ & $1.3132-5.2892$ \\
\hline C.L for con. $12\left(\mu \mathrm{g} \mathrm{ml}^{-1}\right)$ & $11.9792 \pm 0.4018$ & $12.0118 \pm 0.07453$ \\
\hline C.L for con. $9\left(\mu \mathrm{g} \mathrm{ml}^{-1}\right)$ & $9.5443 \pm 0.3506$ & $9.0650 \pm 0.1855$ \\
\hline C.L for con. $6\left(\mu \mathrm{g} \mathrm{ml}^{-1}\right)$ & $5.9556 \pm 0.2930$ & $5.9763 \pm 0.1218$ \\
\hline C.L for con. $3\left(\mu \mathrm{g} \mathrm{ml}^{-1}\right)$ & $3.25149 \pm 0.2051$ & $3.0177 \pm 0.0609$ \\
\hline Enrichment Factor & & 101.807 \\
\hline
\end{tabular}

*Average five measurement

\section{Conclusion:}

Cloud point extraction is a simple, safe, and useful pre-concentration technique to determine Sulphadimidine Sodium by UV/VIS. CPE method is kindliness, selectivity and gave a good RSD and low limit of detection.

\section{Conflicts of Interest: None.}

\section{References:}

1. Amin AS, Zareh MM. Acetylacetone-Formaldehyde Reagent for the Spectrophotometric Determination of Some Sulfa Drugs in Pure and Dosage Forms. Mikro Chem Acta. 1996;124(3-4):227-8.

2. Emmanuel AI, Saganuwan SA, Onyeyili PA. Effects of Piroxicam on Pharmacokinetics of Sulphadimidine in West African Dwarf Male and Female Goats (Capra hircus). Pharm Anal Acta [Internet]. 2017;8(7):1-7.

3. Shawket KJ, Jihan RM. Cloud Point Extraction Methodology for Separation and Microamounts Determination of Lead ( 11 ) and Cadmium ( 11 ) Ions ( NJC ). Iraqi Natl J Chem. 2012;47(11):401-12.

4. Tella AC, Olabemiwo OM, Obiyenwa GK, Salawu MO. A method of assay for the estimation of sulphadimidine in tablets Figure 1: Chemical Structure of Sulphadimidine. African Sci. 2010;11(3):189-93.

5. Tansakul N, Niedorf F, Kietzmann M. A sulfadimidine model to evaluate pharmacokinetics and residues at various concentrations in laying hen. Vol. 24, Food Additives and Contaminants. 2007.

6. Ghanem M, Abu-Lafi S. Development and Validation of RP-HPLC Method for the Simultaneous Determination of Trimethoprim, Sulfadimidine Sodium and Tylosin Tartrate in injectable solution formulation ARTICLE INFO ABSTRACT. J Appl
Pharm Sci. 2015;5(1):94-8.

7. Taha IA. Spectrophotometric Determination of Sulphamethazine by the Diazotisation-Coupling Method with m-Aminophenol as the Coupling AgentApplication to Pharamaceutical. Raf Jour Sci. 2005;16(3):7-14.

8. Ibrahim Zt, A-A Khammas Z, Khadhim Kj. Determination Of Micro Amounts Of $\mathrm{Fe}$ (Ii) And Fe (Iii) In Tea And Rice Samples By Cloud Point Extraction-Spectrophotometry Using A New Chelating Agent. Int J Chem Sci. 2014;12(4):1189207.

9. Naeemullah Kazi TG, Shah F, Afridi HI, Baig JA, Soomro AS. Cloud point extraction and flame atomic absorption spectrometric determination of cadmium and nickel in drinking and wastewater samples. J AOAC Int. 2013;96(2):447-52.

10. Jawad SK, Khaleel LA. Via Cloud Point Extraction Methodology and Acidic $\mathrm{HCl}$ media Extracted of Iron ( III ) by DB18C6.JNSR. 2015;3(5):196-201.

11. Bakir SR, Dhahir A. Cloud Point Extraction spectrophotometric Determination of Trace Amounts of Nickel by SALEN as reagent in waste water of Iraq. Online Int Interdiscip Res J. 2013;3(22499598):9-21.

12. Dhahir SA. Determination of mercury and manganese by using new reagent azo after cloud point extraction for some environmental sample in Iraq. Am J Environ Sci. 2015;11(5):392-401.

13. Article R, Dhahir SA, Mahdi S. Spectrophotometric Determination And Cloud Point Extraction Of Lamotrigine Drug In Pure Form And. World J Pharm Pharm Sci. 2017;6(5):1-27.

14. Dhahir SA, Hamed AH, Ahmed RK, Salman MK. Safety method, Spectrophotometric Determination of Sulfamethaxazole drug in bulk and Pharmaceutical Preparations Material and Methods: Apparatus. Baghdad Sci J. 2010;7(1):1-7. 
15. Dhahir SA. New Azo Coupling Reactions for Visible Spectrophotometric Determination of Salbutamol in Bulk and Pharmaceutical Preparations. Dirasat, Pure Sci. 2011;38(2):153-60.

16. Shatha M. Abdulwahhab M. Spectrophotometric Determination and Cloud Point Extraction of Some Drugs in Pure Form and Pharmaceutical Preparation. MSC $\mathrm{T}$ hesis .College of Science for Women, University of Baghdad. 2017.

17. Abed SS. Flow Injection Analysis ( FIA ) For Some Organic Drug Compounds. College of Science, University of Baghdad. 2012.

18. Dhahir SA, Bakir SR, Cloud point extraction spectrophotometric determination of nickel,copper, cobalt and chromium by 4- HBDA1, 5DPHPas reagent in wastewater of Iraq, ,ESAIJ, 2015; 10(4) : $150-160$

19. He B. Modifications of $\mathrm{Au}$ NanoparticleFunctionalized Graphene for Sensitive Detection of Sulfanilamide. sensors J MDPI. 2018;18(864):1-13.

20. Jawad SK. Joined Liquid Ion Exchange with Cloud Point Extraction Methods for Separation and Determination of Cr ( VI ), Mn ( VII ). Irq. Nat. J. Chem.2012;47(11):1-14.

21. Sakar D, Crnić AP, Janić D, Sakar T. Safety of peroral sulfadimidine sodium treatment in chinchillas ( Chinchilla lanigera ). Vet Arh. 2005;75(4):283-91.

\section{التقدير الطيفي المايكروي والاستخلاص بنقطة الغيمة للسلفاديمادين الصوديوم في المركبات النقية}

رقية هاشم عبد الغني
سعدية احمد ظاهر

قسم الكيمياء، كلية العلوم لللبنات، جامعة بغداد، بغداد، العراق

تم اقتراح طريقتين امتازت كل منهما بالبساطة والسرعة والملائمة لتقدير عقار سلفاديمادين الصوديوم في المبادئ المادة النقية

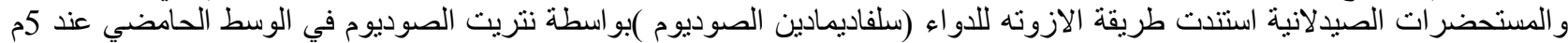

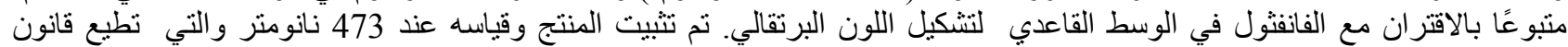

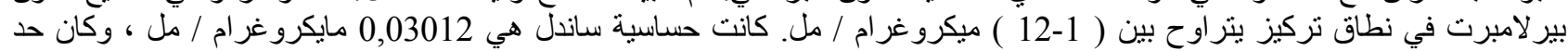

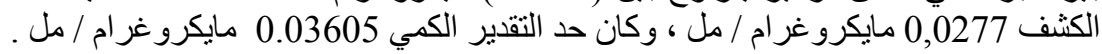

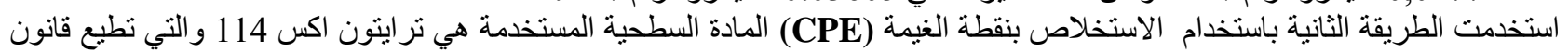

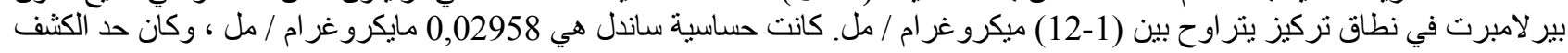

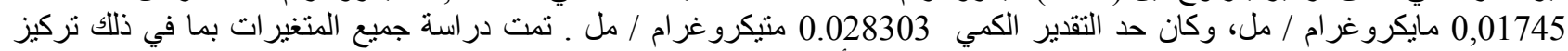

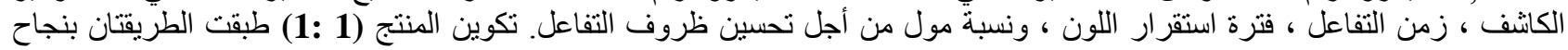

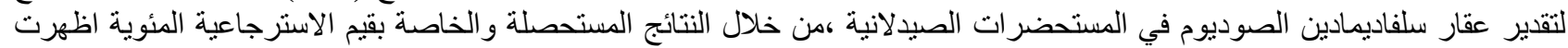
الطريقتان ان لاتاثير للمتداخلات على عملية القياس .

الكلمات المفتاحية: الاستخلاص بنقطة الغيمة، الفانفتول، سلفاديميدين الصوديوم ، ترايتون اكس 114. 